\title{
a touching and contagious \\ captain cook Thinking History through Things
}

\section{- Abstract}

For how long can history, as it is conceived in 'the West', continue to attach itself to an exhausted humanism, where 'man' is central and all the natural and inanimate objects surrounding humans (and linked intimately to human activity) are relegated to the function of support act?

This essay argues from anthropological theory that there are fundamentally different sorts of relationships that humans can entertain with non-humans, and that these relationships can have a magical force. When a monument is placed at the spot where an explorer first touched the land, does this impart a contiguous magic? On the other hand, where the stuff of history seems animated, and spreading out without clear connection to impart some small part of the aura to a doll representing the historical figure, are we not dealing with a sympathetic, contagious magic? This essay will experiment with these nonrepresentational forms of energy as they are transferred in domains associated with the figure of Lt. James Cook.

What, then, is Cook when he is displaced from 'Western' history and spread around cultures like a virus? How precarious or robust, then, are the historical certainties associated with Cookmonumentalised Kurnell and its place in time as 'the birthplace of modern Australia'?

The French philosopher Albert Camus was born in 1913, Jonathan Rée tells us

to an illiterate, fatherless family on a working class estate in eastern Algeria. 'I was poised mid-way between poverty and sunshine', [Camus] wrote, and it wasn't until he went to Paris and saw what it was like to live in a cold climate that he understood social injustice. Poverty was proof that history is unfair: the sun was a reminder that 'history is not everything'. 
History produces perceptions of unfairness, it also produces its own unfairnesses. Here, under this antipodean sun, ancient philosophy reminds us that history is not everything, and also that history was only a recent blow-in and sometimes a crude technology for triumphantly putting dates on things, like monuments and inventions, and allowing this world to be infected with the virus of modernity to ensure that the so-called ancients, the indigenous peoples, remain ontologically prior.

In Australian history, Captain Cook has become a pivot for these false perceptions of 'ancient' and 'modern'. This is perhaps why, as a sense of historical injustice drove people in the 1960s to do the work of assembling Aboriginal histories, that the revisionist backlash that followed it in the 1990s centred on Cook as a necessary and heroic redeemer of white centrality, if not superiority. So in order to experiment with history, and to gain a metahistorical foothold, I want to look at history, and the figure of Cook, from the vantage point of culture.

In his work on social memory, Chris Healy set out the parameters for the kind of experimental study my colleague Katrina Schlunke and I have undertaken, not 'Captain Cook, a name which refers us not to an actual historical figure', but Cook as 'an enduring icon, a huge network of narratives, images and ceremonies' ${ }^{2}$ as he goes on usefully to contrast the building up of the whitefella nationalist mythology (Cook as origin, as hero of science and exploration, and even as a lower-class battler) with the recent disruption by Aboriginal stories of Cook as thief and violator.

History, like many other things, is 'constructed'. It is the product of all the hard work of observers, opinion-makers, teachers, writers, artists of various sorts, archivists and the builders of monuments, museums, texts, databases and commemorative events. These various activities are simultaneous and interlinked, spreading out over the country, opening the archive onto past materials and ideas, as well as projecting some of those, as political hopes, into the future. This 'assemblage' of history is a construction of a different nature to the notion of construction of history as a set of representations, which tends to derive from a linear model of subject—text—object, a 'correlationist' model according to which the world appears to consciousness via the filters of culturally specific restrictions of language. This post-Kantian model holds that we can neither conceive of humans without an exterior world, nor of world without humans, but must base all philosophy in a correlation between the two. ${ }^{3}$

Correlationism is orthodox among those continental philosophers for whom the critique of the subject-object dualism and of representation is now a familiar critical move. So their philosophical limit is that the world has to be represented to humankind, the final arbiter of their own earthly destiny: what matters to 'man' is 'himself'. Having abandoned the knowabilty of the world to the sole medium of language, with all its slipperiness, these narcissistic humanists are left 'to celebrate the irreducible wonder of human subjectivity'. ${ }^{4}$ 
And indeed, the subject of history is a certain type of person: morally righteous (often), omniscient (usually), dislocated from the places where things are happening, and wearing tweed, if we think, perhaps, of the English invention of the 'History Men'.

Taking language out of the equation, and decentring the human subject, does not join forces with those conservative positions which rely on the transparency of the objective fact. Ultimately, they are running on the same correlationist philosophy, but, not yet having arrived at the critique of representation, they merely assume that the correct arrangements of facts will lead to a singular history they are happy to call the truth. In my model, taking language out and decentring the subject does not eliminate them either, it puts them on the same surface as all the other stuff that might be concerned with history-making. 'Concern' is a key Latourian term here, for what matters to history-makers, the injection of values, is also part of the overall assemblage. History does not make itself without the continual participation of values of a philosophical origin or social availability. They are there, overjoyed, at the birth of every new fact, they are there sternly interrogating new claims of evidence.

Let's conceive of history-making as occurring within a political ecology. What that hopes to achieve, as a model and as a research practice, is the continuation of anti-foundationalism (there are no 'basic concepts', only concepts that practically work), the elimination of metaphor in the architecture of the model (for example: 'depth'), and the observation of actual relations among objects, concepts, humans and other living things. This is a living and growing system where 'actual relations' refers to things that are articulated for all sorts of purposes that further the continuation of the system.

A political ecology of a field like history will ultimately influence historiography because it will allow all sorts of agents to participate in history-making: technologies, animals, even elusive concepts like 'atmosphere' or 'mood'. We might ask what kind of 'atmosphere' also contributed to a renewed interest in Captain Cook in Australia in the 1990s? We might thus experiment with the elements of a living ecology to see what ingredients cause the system to thrive, or not. This approach to history-making is quite at odds with a dialectical model based on the work of negative critique, where humans, with their special cultural attributes (like language), are locked in a to-and-fro debate with 'the world' with its supposedly objective attributes.

As an example of moving the terms of debate, let me tell the story of my argument with John Howard. After he asserted the importance of learning dates at a national summit on the teaching of history, I wrote a response in the Sydney Morning Herald, 'Experimental history won't change the Battle of Hastings', thus called because Howard's insistence was that students are failing to learn significant facts, and that this is the fault of 'postmodern relativism'.

I pleaded that it would be difficult to find adherents of 'postmodern relativism', and that if one did, they would have no problem with facts. I might have suggested, though, that 
postmodernism was useful for interrogating some of the certainties of European modernity, but that that period was rich in experimental thought, not only cultural pluralism, but also Einstein was there 'messing with reality' in the form of the theory of relativity. I suggested that Howard's dogmatic insistence on facts was uninspiring and anti-intellectual—nothing unusual there. I argued that what I would like to call 'experimental history' is not experimental in the artistic sense-like the writers' workshop—but radically empirical à la William James, not excluding anything as a possible actor in a virtual situation, giving rise to an event. So experimental thinking opens up new domains of facts. 'What if there were such a thing as women's history', someone once asked-and a new subject was born. It is a question of adopting a new perspective, as Henry Reynolds said, as he, too, opened up the new field of Aboriginal history, making him one of the most influential public intellectuals of the last couple of decades.

His critics make him out to be controversial and politically correct. But adding new chapters on Aboriginal history to the Australian story has not had the effect of wiping out Captain Cook, it has simply added something compelling as a story and an argument. Its politics is motivated by justice and inclusion, democratic ideas people generally agree with.

Reynolds's new perspective tells us that Australian history did not just begin with Cook or the First Fleet. 'What was happening on the other side of the frontier?' he asked. While he was working in the document archives turning up neglected materials on early colonial life, including massacres, archaeologists also came up with facts that added new first chapters to the human history of the continent, uncovering the stories written in the sands of Lake Mungo, and in thousands of camp sites and shell middens. ${ }^{5}$

The experiments also were inflected by new methods and new technology, like tape recordings, which gave us ways of valuing and interpreting the living traditions of oral history. An experimental thought that highlights a virtual field like women's history or labour history will go nowhere unless the archive and the evidence is there to be assembled and allow the field to actualise and thrive. So I should reiterate that this is not the textual 'constructionism' of the kind a Windschuttle might like to fuse with 'fabrication', but construction as an assemblage of lots of real things.

Things, however, are strange, and humans relations with things have a range of traditionally ascribed magical properties. These take us to anthropology to help us to understand something about the popularity of Captain Cook, about his synchronic 'spread' rather than his diachronic links. The structure of the most pervasive myths about Cook relate to him as a historical figure, so the experiment that Katrina Schlunke and I have carried out, consisted, in one of our first moves, in taking him out of history, at least as we talked about the subject, in our preliminary analysis. For indeed, despite the way official and popular histories talk 
about him, Cook has had one foot, as it were, well and truly out of history for a long time, and has spread far and wide in the spaces of culture. When you encounter him metonymically as an Endeavour in the name of a high school in the Sydney suburb of Rockdale, or as a miniature Endeavour in a bottle, or as the name of a convenience store, history is not the narrative that first springs to mind. It is something more cultural like a sense of identity or belonging. In fact, as Greg Dening has demonstrated in relation to Bligh, ${ }^{6}$ one of the best ways to make one's way into history is via popular cultural consumption, hence, The Death of Captain Cook; A Grand Serious-Pantomimic-Ballet, in Three Parts. As now Exhibiting in Paris with uncommon Applause, with The original French Music, New Scenery, Machinery and Other Decorations. ${ }^{7}$ This must be an English celebratory 'corroboree', no cold one-dimensional text here; it has all the hall-marks of ritual. There is simultaneous multiple-coding in poetry, melody, repetition and choreography, all the elements to make the affective body thrill in sympathy-and remember.

We are touched. And this brings us to the anthropological classification of human societies, as proposed by Philippe Descola, ${ }^{8}$ giving us another way of thinking about the ecology of history-making sites without having time as a founding methodological concept. Contiguity is one of the ways humans organise their relationships with things, and in the process, and in the relationship, attribute things with magical power. ${ }^{9}$ But I am putting this badly, for it is only modern Western culture that has the habit of classifying the things of the world into Nature on the one side and Culture on the other, where nature has its 'laws' accessible only to Science, and cultures on the other side are charmingly diverse and vary by mere convention. In the face of Science, they don't matter for knowledge (but they matter for social arrangements, that is why so much blood has been spilt over religious differences, and over history). What I should say is that there are continuities along nature-culture dimensions, and there are different practices for expressing relationships in those dimensions. So when an Indigenous person says that a certain picture of a sacred tree 'is' me, or it 'carries my power', she is not saying 'it is something (out there in the world, out in Nature) which represents me'. Far from expressing the image of some kind of spiritual harmony with Nature, she is not working with a concept of Nature at all. Such a generality, in the singular, is completely irrelevant to her practice. So when she expresses a particular relationship it is significant precisely because it does not 'bridge' anything. This is what anthropology calls totemism, a moral and material continuity running between humans and non-humans.

In his major 2005 book, Par-delà nature et culture, Descola distinguished four broad ontological cultural types on a world scale: totemism, animism, analogism and naturalism. Totemism (characterising Australian Indigenous societies, for instance) sees the same internal stuff running through the person and their totem, and they resemble each other on the outside. ${ }^{10}$ 
Animism attributes non-humans with the same interiority as humans, but they are physically different. This more anthropomorphic category sees a person in a relation to a plant or animal as if that thing were animated by the same spirit. The metonymy of a voodoo doll is an example. Analogism and naturalism will not serve us here, suffice to say that the former describes a social ontology based on 'cosmic' systems of correspondences as in many Eastern cultures (astrology for example). Naturalism is based on the Western nature-culture divide, where humans and non-humans are composed of the same basic natural stuff (for example atoms), but the humans are radically separated from the rest because of their cultural capacities, like consciousness and motivation.

Let us now take this apparatus into the field to experiment with taking Cook out of history. I want to go to three Cook sites: Kurnell, Cairns and my own little wunderkammer in my office at work.

Kurnell, readers need not be reminded, is an iconic Australian site: 'the birthplace of modern Australia', because Cook first set foot on the continent here, and because the slogans of Sutherland City Council keep reminding us. There is a lot to be said about the contested meanings of this place, ${ }^{11}$ but I want to use it as a site for two little experimental moves. The first is about contiguity and totemism. Like many Cook sites it is marked with a monument, sited only metres from the supposed actual landing spot. Visitors can thus go unerringly to the very spot itself. Putting aside the spurious observation that the monument rises vertically in stereotypical 'totem-pole' fashion, the monument remains totemistic in the sense I described because 'the same stuff run[s] through the person and their totem, and they resemble each other'. This 'Cook spirit' runs in that sense through all the sites marked totemically across the world, mostly following his travels. This is not the kind of totem, as in Aboriginal Australia, which marks continuity in a natural-cultural space, where a clan or person 'is' also the bandicoot totem, it is a weaker version because it is a 'totemic marker', a kind of 'representation', but it does much more than signify. Its presence is ergative (to borrow a term from the linguistics of Aboriginal languages), it does work because the social vectors converging in it make it event-like

Another title for this paper could have been 'History as an ergative language', because that emphasis would be useful for my conceptual purposes. Indo-European languages are often classified as Nominative-Accusative languages. That means that the subjects of both transitive and intransitive verbs are marked in the same way, while the object of a transitive verb has a special ending (the accusative). In ergative languages (many Aboriginal languages, Basque and Tibetan), it is the agent of a transitive verb which is marked differently. The object of an action and the subject of an intransitive verb are treated the same. The point is that the agent of the transitive verb is seen to 'work', the event-creating transitive verbs 
have a specially marked subject. R.M.W. Dixon, in his Ergativity, makes the point that such grammatical differences are arbitrary, and need not inscribe differing world-views. ${ }^{12}$ Maybe so, my point is rather more heuristic, a focus on the performative work of language leads us away from subject-object as the primary conceptual relation of representation.

There can be no claim that such totemism might integrate Cook into a viable local totemic system, it hasn't happened. ${ }^{13}$ Rather, this mode of marking Cook's presence is overlaid with Western semiotics (the icon represents the subject), but the stronger magical connections people are wont to make, I would argue, lie in the contiguity of the site, and the same contiguity is repeated in every trace that has come down to us: Cook's drinking mug, articles of clothing, artefacts he collected, even a louse collected from an albatross on a Cook voyage labelled under Cook's name in the McLeay Museum at the University of Sydney.

In June 2006, Katrina enjoyed taking me back-because she had been there before-to the Captain Cook Motel in Cairns where there is a huge ferro-cement statue of Cook, still standing there amid the rubble of the now-demolished motel. It is an impressively tawdry example of those Australian gargantuan region-markers: this would be The Big Cook. His right hand, extending out and slightly raised, is opening up imperial space and time, the gesture derived as it is from the famous Phillips-Fox painting about the first landing. Now, since Cook had never been to Cairns, this is no claim to contiguity, that magical connection lies further up the coast at Cook Town, rather, I would argue, it is a case of contagion or 'spread'. Cookiness here is manifest in a different guise. The statue looks like him, enough to make the representation clear, but like so many of the tourist trinkets, or the more diffuse allusions (as in the name of a street or of a convenience store chain), the resemblance is not the issue, it is that the object contains something of the spirit of Cook. We value it for this tokenistic reason, not because it was in a contiguous relationship with him. Objects infected by contagion are animistic in the double sense of the sacred: things named 'Captain Cook' project an aura of protection from desecration and, at the same time, contain a vulnerable essence. As far as I know the Big Cook still stands there in Cairns, after many debates about what is to be done with this objectively worthless but culturally powerful object. I have another little Cook vehicle, brought as a present from Whitby by Katrina, an Endeavour in a bottle. I wonder now about its miniature power as it sits in my cabinet of curiosities in my office.

To return to Kurnell for the second historical experiment, I would like to see if there is evidence for proposing that Kurnell is not the 'birthplace of modern Australia'. When an evening tabloid in Sydney reported something of the atmosphere of defending a white sacred site under the banner KURNELL'S EUROPEAN SYMBOLS FACING AXE, Malcolm Kerr, Liberal MP for Cronulla, reacted by saying that some proposed changes to the site would be 
'an example of "political correctness" ... I think they are downgrading Cook, and there should be a bit of equity in relation to history'. Then Mr Kerr added, using the key phrase: 'Let's have more credit for Cook's achievements in a place that is the birthplace of modern Australian culture. ${ }^{14}$

It packs a lot in, this phrase about the confluence of place and time, the first place and the first time. Knowing that the Indigenous people were here first, the word modern becomes a pivotal concept, making everything that Cook stood for the bearer of modernity, science and rationality. But could he be sure he was 'absolutely modern'? Can we be sure that we, today, are similarly the bearers of an unsullied modernity, derived from Europe, the origin of everything that is civilised and superior? To the extent we have doubts about this, that we can be convinced that there are 'alternative modernities' in the world, then we have to doubt that Kurnell is such a firm pivot in the arrival of modernity in Australia. Perhaps also the modernisation process has not gone to completion for settler Australians, perhaps it never will. ${ }^{15}$ We still have ancient European rituals, and are we not barbarous or primitive from time to time, with violence on the beaches, reminding us of Cook travelling the world firing his guns at people across the sands in the heat of the sun?

And the Aborigines, on what grounds are they excluded from their own versions of modernism, which I have defined as inventive and rapid adaptation to changes? ${ }^{16}$ A culture is not modern simply because it has been through an industrial revolution, or because it has large permanent buildings, firearms, enclosed land and monocultural agriculture, or a centralised government. In the scale of world history, are these such great things? Nothing at Kurnell suggests that Aborigines were stuck in the Stone Age and not always changing and adapting to circumstance, and the records of encounter and the subsequent history provide ample evidence for this. But the key concept, the modern, especially in its pivotal role at Kurnell, continues on its mission to do nothing much more than divide the achievements of colonial Australia from the richnesses of Indigenous civilisation.

As long as history has Man central stage and things (animate, inanimate, natural) as a support act, the kinds of continuities and necessary dependencies among them will be obscured. 'We' have always thought and acted in conjunction with things: telescopes and stars, falling apples, boomerangs and platypuses. So what kind of subject of history might replace that of the figure of the human with a progressive modernist destiny? I have suggested, in a Latourian manner, that matters of concern might lead us to a parliament organised as an ecological assemblage, where questions of what is most urgently at stake-how do all of us decide the ranking of problems? - displace the disinterested pursuit of objectivity. Our new historian is a consummate negotiator in a heterogeneous environment where the historical is often treated as political and as personal, where no amount of objectivity seems to be able to douse enflamed passions. Our new subject of history has found that the power driving 
history-making is dispersed and multiple, that is, the situation is rarely a clear case of the Self vs the World, or of Left vs Right, but one of multiple human and non-human stakeholders putting their arguments. The historical world we build is not therefore one consisting primarily of 'constructed' representations, it is a negotiable world of heterogeneities.

What unites the miniature Endeavour in the bottle with the real ship, or the ferro-cement statue with a real human being called James Cook? It is not simply the operation of magic or a leap of faith across the gap that representational philosophies mysteriously construct. That would be lazy as well as magical thinking. It is, in fact, the hard and repetitive work of arguing for, and constructing, the successive stages of equivalence. People do this each time they are prepared to say $\mathrm{X}$ is 'the same as' $\mathrm{X}$ '. This is the kind of work performed by historians when they say that the man Cook and the boat at Poverty Bay in Aotearoa are 'equivalent to' the man and the boat that later sailed into Botany Bay. Of course they are the same, you may say, despite minor changes, like the man Cook might be a little more wary about using his guns. Without such continuities where would history be? Indeed, history would reside in the narration of the slight differences, and that is what happens in cultural analysis too when its knowledge acquisition describes real and materially explicit chains of translation.

STEPHEN MUECKE is a writer and research professor in Cultural Studies at the University of Technology, Sydney. He has written on Indigenous Australia (Ancient \& Modern: Time, Culture and Indigenous Philosophy, 2004) and more recently on the Indian Ocean (ed. with Devleena Ghosh, Cultures of Trade: Indian Ocean Exchanges, 2007). <stephen.muecke@uts.edu.au>

Thanks to my dear friends and colleagues Tara Forrest, Jan Idle and Katrina Schlunke for help with this paper, as well as the kind and constructive comments of the Cultural Studies Review's anonymous reviewer.

1. Jonathan Rée, 'Bound to be in the Wrong', London Review of Books, 20 January 2005, p. 20

2. Chris Healy, From the Ruins of Colonialism: History as Social Memory, Cambridge University Press, Melbourne, 1997, p. 11.

3. Quentin Meillassoux, Après la Finitude: Essai sur la Nécessité de la Contingence, Seuil, Paris, 2005, pp. 18-24.

4. Isabelle Stengers, Penser avec Whitehead: Une libre et sauvage creation de concepts, Seuil, Paris, 2002, p. 22.
5. Sydney Morning Herald, 31 January 2006, p. 11.

6. Greg Dening, Mr Bligh's Bad Language: Passion, Power and Theatre on the Bounty, Cambridge University Press, Cambridge, 1992.

7. At the Theatre-Royal, Covent Garden, T. Cadell, (printer), London, 1789.

8. Phillipe Descola begins his Par-delà nature et culture (Gallimard, Paris, 2005) citing Montaigne on a unifying nature and then stating: 'a few decades after Montaigne's death ... nature stopped being a way of unifying the most disparate of 
things to become a domain of objects governed by autonomous laws against the background of which a diversity of human activities could indulge their charming displays. A new cosmology was just born, a prodigious collective invention which offered an unprecedented framework for the development of scientific thought and of which we continue to be, at this beginning of the twenty-first century, the slightly distracted guardians.' p. 9

9. I am adapting the famous model of Sir James Frazer. He had sympathetic magic as a general category, with homeopathic (the 'Law of similarity') and contagious magic as subcategories. In wishing to make the distinction between the contiguous and the contagious (which he does not do), I have had to align contagion with practices of an animistic sort. See J.G. Frazer, The Golden Bough: A Study in Magic and Religion, Limited Editions Club, New York, 1970, p. 18.

10. Descola, p. 176.

11. Maria Nugent, Botany Bay: Where Histories Meet, Allen \& Unwin, Sydney, 2005
12. R.M.W. Dixon, Ergativity, Cambridge University Press, Cambridge, 1994, pp. 214-15.

13. But see Maria Nugent's interesting analysis of the comings and goings of Aboriginal figures in the finding and marking of whitefella sites. Far from keeping the blackfellas at bay, she demonstrates that on many occasions they are brought back or come back to the sites for continued interaction and participation in history-making. From the Aboriginal point of view, could their participation be part of an attempt to integrate the whitefella? 'Historical Encounters: Aboriginal Testimony and Colonial Forms of Commemoration', Aboriginal History, vol. 30, 2006, pp. 33-47.

14. As quoted in Stephen Muecke, Ancient \& Modern: Time, Culture and Indigenous Philosophy, Sydney: UNSW Press, 2004, pp. 6-7.

15. Muecke, Ancient $\&$ Modern, See also Stephen Muecke, "I Don't Think They Invented the Wheel": The Case for Aboriginal Modernity', Angelaki, vol. 9, no. 2, August 2004, pp. 155-65.

16. Muecke, Ancient \& Modern, pp. 5-6. 